Kemudi: Jurnal Ilmu Pemerintahan | 215

Volume 05 Nomor 02 Februari 2021

2622-9633 (Online)

Open Access at: https://ojs.umrah.ac.id/index.php/kemudi

DOI: https://doi.org/10.31629/kemudi.v5i02.2853

\title{
Inkonsistensi Kebijakan Pemerintah Pusat Dalam Penanganan Covid-19 Di Indonesia
}

\author{
Herni Marina \\ Mahasiswa Magister IImu Politik \\ Universitas Diponegoro \\ marinaherni09@gmail.com
}

\begin{abstract}
Until the end of 2020, the Covid-19 curve in Indonesia has not decreased, and even continues to increased. This indicate something wrong with government policy. With the form of the state of Indonesia as a nation state "decentralized", national policies become the reference policies in local policies. Its be a determining factor in facing this pandemic. This paper discusses the inconsistency of national policies with implications for local governments. The research used a qualitative approach by utilizing descriptive analysis methods. Data sources used are secondary data from journals, books, government websites, electronic media, legislation, and other studies. Data collection techniques using the method of document review. The results of the research identified inconsistencies in national policies, namely unclear direction of regional quarantine policies, rapidly changing transportation policies, and government lack of transparency in health policies. The result of this inconsistency has implications for local governments into deficit budget, an increase in the number of positive patients in the regions, a decrease in public awareness of obeying regulations. Based on this, the pattern of policy relations built by the government in terms of handling Covid-19 in Indonesia is centralized (Top-Down).
\end{abstract}

Keywords : Inconsistency Policy, Governance Relations, Central Government, Local Government, Covid-19

\begin{abstract}
ABSTRAK
Sampai akhir Tahun 2020, kurva Covid-19 di Indonesia belum juga melandai bahkan terus naik. Hal ini bisa jadi mengindikasikan ada yang salah dengan kebijakan pemerintah. Dengan bentuk negara Indonesia sebagai negara kesatuan "terdesentralisasi", kebijakan pemerintah pusat menjadi hulu kebijakan-kebijakan di daerah, yang mana hal ini menjadi faktor penentu dalam menghadapi pandemi ini. Tulisan ini mendiskusikan inkosistensi kebijakan pemerintah pusat implikasinya pada pemerintah daerah. Penelitian ini menggunakan metode kualitatif dengan sumber data yang digunakan adalah data sekunder yaitu data yang diperoleh dari jurnal, buku, website pemerintah, media elektronik, Perundang-Undangan, dan kajian lainnya. Teknik pengumpulan data menggunakan metode telaah dokumen. Hasil penelitian mengidentifikasi terdapat inkonsistensi kebijakan pusat yaitu tidak
\end{abstract}


jelasnya arah kebijakan karantina wilayah, kebijakan transportasi yang berubah-berubah dengan cepat, serta ketidaktransparan pemerintah pada kebijakan kesehatan. Akibat dari inkosistensi ini berimplikasi pada daerah antara lain daerah kekurangan anggaran, meningkatnya jumlah pasien positif di daerah, menurunnya kesadaran masyarat mematuhi aturan. Berdasarkan hal tersebut, Pola hubungan kebijakan yang dibangun pemerintah dalam hal penanganan Covid-19 di Indonesia adalah sentralistik (Top Down).

\section{Kata Kunci: Inkosistensi Kebijakan, Hubungan Pemerintahan, Pemerintah Pusat, Pemerintah Daerah, Covid-19}

\section{Pendahuluan}

Kini dunia menghadapi musuh besar bersama yang tidak terduga mampu menghancurkan sendi-sendi kehidupan masyarakat bahkan negara yaitu Corona Virus Disease 2019 (Covid-19). Masalah Covid-19 menjadi agenda besar negara-negara dunia, bukan hanya menjadi isu kesehatan, bahkan isu sosial, ekonomi bahkan menjadi isu politik. Virus ini telah menginfeksi seluruh negara di Dunia dengan jumlah pasien positif mencapai 75 juta orang dengan angka kematian hampir 1,8 juta orang pada akhir 2020 ini, bahkan jumlah ini terus mengalami lonjakan tiap harinya. Baik negara maju, berkembangan dan miskin semuanya mengalami kegagapan kebijakan menghadapi pandemic Covid-19 ini. Amerika Serikat yang merupakan negara adidaya tercatat sebagai negara dengan kasus tertinggi Covid-19.

Tercatat konfirmasi pertama munculnya penularan Covid-19 di Kota Wuhan, Provinsi Hubei, Cina yang mempunyai riwayat pernah mengunjungi pasar ikan Huanan pada Desember 2019. Pada Januari 2020 mulai terjadi konfirmasi kasus Covid-19 diluar Cina, yaitu dimulai dari Thailand, Jepang yang kemudian akhirnya World Health Organization (WHO) menetapkan wabah ini menjadi menjadi darurat kesehatan global. Pada tanggal 23 Januari 2020 dilakukan penutupan Kota Wuhan oleh Cina.

Indonesia sampai saat ini dapat dikatakan menjadi salah satu negara penyumbang angka positif dan meninggal terbesar di dunia bahkan menjadi terbesar di Asia Tenggara. Kasus konfirmasi pertama Covid-19 di Indonesia pada tanggal 3 Maret 2020 dengan mengkonfirmasi 2 orang positif Covid-19. Dan terhitung hanya butuh 38 hari saja Covid-19 menginfeksi seluruh provinsi di Indonesia. Padahal sebelumnya WHO sebenarnya telah menegur pemerintah Indonesia yang terkesan lamban menanggapi pandemic korona. Bahkan pada awal Februari 2020 WHO menyangsikan bahwa belum adanya 
konfirmasi Covid-19 di Indonesia dikarenakan ketidakmampuan pemerintah Indonesia untuk mendeteksi Covid-19. Direktur Jenderal WHO, Tedros Ghebreyesus meneken Surat kepada Presiden Joko Widodo tanggal 10 Maret 2020 yang isinya antara lain mengapresiasi upaya yang dilakukan pemerintah Indonesia mengatasi dampak virus korona, pentingnya koordinasi dan kolaborasi pemerintahan, pentingnya deteksi dini melalui desentralisasi pengujian spesimen virus sehingga dapat dengan cepat memetakan penyebaran virus, dan segera mendeklarasikan darurat nasional Covid-19.

Sampai akhir Tahun 2020, kurva Covid-19 di Indonesia belum juga melandai bahkan terus naik. Terhitung menurut situs resmi pemerintah melalui covid19.go.id per Tanggal 14 Desember 2020 terdapat 623.309 orang pasien terkonfirmasi positif covid-19 dengan jumlah pasien meninggal sebanyak 18.956 orang dengan Provinsi 3 terbanyak untuk konfirmasi positif adalah DKI Jakarta 152 ribu kasus, Jawa Timur 70 ribu kasus dan Jawa Tengah 66 ribu kasuh. Jumlah ini akan terus naik bahkan kasus positif harian mengalami kenanikan tiap harinya dengan rekor harian tertinggi mencapai 8 ribu orang positif.

Begitu masifnya gempuran pandemi Covid-19 menghadapkan pemerintah Indonesia berbagai macam persoalaan mulai dari adanya simpang siurnya informasi yang diterima masyarakat berkaitan dengan Covid-19, tidak sesuainya jumlah kasus konfirmasi positif Covid-19 antara pusat dan daerah, penentuan status kedaruratan daerah, PHK besar-besaran, karantina wilayah, vaksinasi dan lain sebagainya yang menyebabkan kegaduhan di pemerintah dan masyarakat. Hal ini bisa jadi mengindikasikan ada yang salah dengan kebijakan pemerintah.

Dengan bentuk negara Indonesia sebagai negara kesatuan "terdesentralisasi", kebijakan pemerintah pusat menjadi hulu kebijakankebijakan di daerah menjadi faktor penentu menghadapi pandemi ini. Praktek desentralisasi yang diterapkan di Indonesia mendapat tantangan besar dalam menghadapi pandemi ini karena pusat terkesan memonopoli kebijakan tetapi dilain sisi, daerah menghadapi kegaduhan akibat tumpang tindihnya kebijakan yang diterapkan pusat. Hal ini menurut penulis penyebabnya salah satunya adalah tumpang tindihnya peran pemerintah pusat dan daerah.

Tumpang tindih kewenangan pusat dan daerah bukan hal baru dalam ketatanegaraan Indonesia. Indonesia yang menganut sistem negara Kesatuan 
memberikan hak otonomi daerah pada pemerintah daerahnya sering dihadapkan dengan persoalan tumpang tindih kewenangan ini. Menurut UU Nomor 23 Tahun 2014 tentang Pemerintah Daerah mengamanatkan bahwa urusan pemerintan itu terbagi atas urusan pemerintahan absolut, urusan pemerintahan konkuren. Urusan pemerintahan absolut dilaksanakan mutlak oleh pemerintah pusat yaitu urusan hubungan luar negeri, pertahanan, keamanaan, yustisi, agama, moneter dan fiskal, sedangkan urusan pemerintahan konkuren adalah Urusan Pemerintahan yang dibagi antara Pemerintah Pusat dan Daerah provinsi dan Daerah kabupaten/kota yang menjadi dasar pelaksanaan Otonomi Daerah. Salah satu urusan pemrintahan konkuren adalah urusan kesehatan. Dengan adanya urusan yang diurus bersama hal ini membuat terkadang urusan ini menjadi tumpang tindih. Hal ini bisa jadi karena urusan tersebut tidak secara jelas diatur oleh peraturan perundang-undangan dan bisa juga karena prilaku aktor pemerintahan yang sekaligus aktor politik dan menjalin relasinya antar pemerintah tinggi dan rendah.

Menurut Mas'udi dan Astriana di level negara sinergi antar lembaga baik yang bersifat horizontal maupun vertikal menjadi kunci efektifitas penanganan. Namun hal ini tidak mudah ketika dihadapkan pada sistem politik dan pemerintahan yang bersifat desentralisasi dan plural, terlebih secara politik mengalami fragmentasi, sinergi dan koordinasi pemerintah menjadi tantangan utama yang harus dikelola. Ini terlihat di Indonesia yaitu terjadinya politisasi pandemi diantara aktor-aktor kunci pemerintah (Mas'udi \& Winanti, 2020).

Indonesia pada awal mulanya dapat dikatakan menyepelekan virus ini, bahkan menurut Wijayanto selaku Direktur Center untuk Media Lembaga Penelitian, Pendidikan dan Penerangan Ekonomi dan Sosial (LP3ES) ${ }^{1}$ terdapat 37 pernyataan blunder pemerintah berkaitan dengan virus Covid-19 ini dari sejak masa pra krisis, awal krisis, masa krisis. Hal ini menghasilkan sentimen yaitu pemerintah tidak serius menghadapi pandemi Covid-19, selain itu masyarakat gagal memepersiapkan diri menghadapi Covid-19.

\footnotetext{
${ }^{1}$ Kajian Online LP3ES Petaka Karena Kata : Blunder Komunikasi Politik, Kabinet Jokowi di Era Pandemi Tanggal 6 April 2020
} 


\section{Tinjauan Pustaka}

Penelitian sebelumnya yang dilakukan oleh Gustomy mendapati bahwa Polarisasi politik dan agama di Twitter masih terus terjadi dipandemi (Gustomy, 2020). Hal ini juga diperparah menurut Agustino (2020) karena sense of crisis pemerintah tidak ada pada penyebaran covid-19 melalui pernyataan para menterinya sehingga keputusan yang diambil menjadi lambat. Selain itu pengendalian penyebaran Covid-19 di Indonesia menjadi tidak efektif ditambah lagi dengan lemahnya koordinasi pusat dan daerah dan ketidakpatuhan warga atas himbauan pemerintah. Menurut Muis transparansi negara dunia cara jitu menghadapi Covid-19 (Muis, 2020). Hal ini sama dengan hasil analisis dan paparan yang dilakukan oleh Drone Emprit pada sosial media dan portal berita online mengenai Analisis Persepsi dan Emosi Publik Terhadap Penanganan \#COVID19 Oleh Pemerintah (7-13 Maret 2020) (https://pers.droneemprit.id/analisis/ diakses pada 19 Juni 2020) menemukan bahwa masalah utama yang dihadapi pemerintah adalah soal kepercayaan publik kepada pemerintah. Tidak dibukanya data ke pada publik karena takut menimbulkan kepanikan pada publik diawal pandemi, ternyata tidak terbukti.

\section{EMOSI PUBLIK TERKAIT VIRUS KORONA DI INDONESIA}

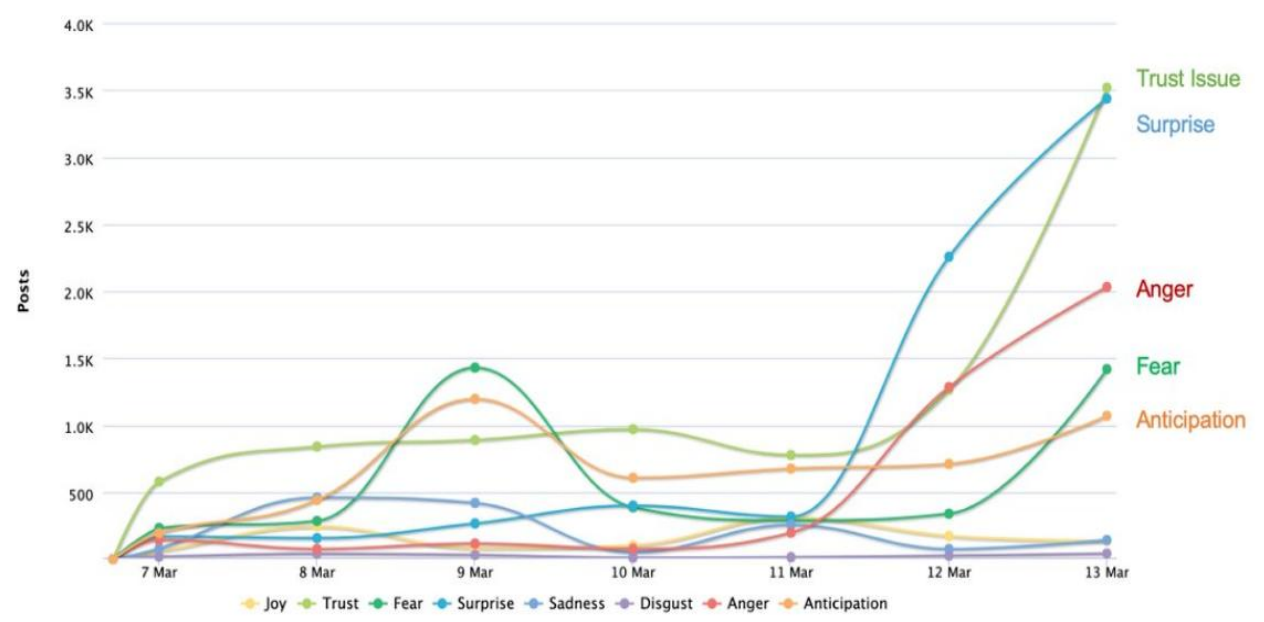

Senada dengan hal tersebut berdasarkan temuan Research Centre for Politics and Government (PolGov) Departemen Politik dan Pemerintahan (DPP) 
UGM melalui Laboratorium Big Data Analytics yang menganalisis perbincangan pada platform Twitter dalam rentang 14 Mei hingga 18 Mei 2020 pada twitter yang diamplifikasi oleh publik melalui tagar \#indonesiaterserah dan \#terserahindonesia mengintepretasikan pertama, masalah kepercayaan publik dan sinisme terhadap pemerintah atas penanganan Covid-19 di Indonesia yang dianggap tidak konsisten; kedua, publik mulai cemas terhadap arah perkembangan perilaku masyarakat yang mulai mengabaikan protokol kesehatan yang ada (Kurniawan, Prastyo, Pamungkas, Ardianto, \& Farid, 2020).

Pembahasan Covid-19 ini cukup baru dan menjadi topik cukup yang hangat baik dikaji dalam ilmu kesehatan maupun ilmu sosial. Tulisan ini hadir mengisi kekosongan yang belum digali oleh penulis sebelumnya seperti Yunus dan Rizki membahas kebijakan lockdown diperlukan dalam memutus penyebaran Covid-19 di Indonesia dan dengan kerja sama pemerintah dan masyarakat diperlukan untuk meminimalisir dampak negatifnya (Yunus \& Rezki, 2020). Hal serupa juga dibahas Samudro dan Majid kebijakan PSBB dan Gugus Tugas lebih tepat ketimbang Lockdown. Sementara itu kebijakan pelaksanaan rapid test, karantina maupun operasional RS untuk penanganan Covid-19 dan kebijakan physical distancing / social distancing dapat menurunkan jumlah kasus Covid-19 di Indonesia (Samudro \& Madjid, 2020). Sementara itu disisi kebijakan daerah Rembulan dkk membahas klasterisasi Covid-19 di provinsi di Indonesia (Rembulan, Wijaya, Palullungan, Alfina, \& Qurthuby, 2020). Kemudian Ginanjar membahas bahwa Desentralisasi di bidang kesehatan menyebabkan standar layanan kesehatan dasar di daerah bervariasi tergantung pada komitmen dan kemampuan fiscal di daerah (Ginanjar, 2020). Sulistiani dan Kaslam yang mengambil studi di Jawa Tengah mendapati bahwa Kebijakan Jogo Tonggo kurang berhasil karena kurangnya kesadaran masyarakat terhadap bahaya wabah Covid-19. (Sulistiani \& Kaslam, 2020). Covid-19 dan Normal Baru mempengaruhi RPJMN Indonesia. Pemerintah punya 3 opsi kebijakan pertama tetap pada rencana semula, revisi sebagian, atau mengganti total RPJMN (Muhyiddin, 2020).

Tulisan ini cukup berbeda dengan tulisan sebelumnya karena ingin menggali pada inkonsistensi kebijakan pemerintah pusat yang berimplikasi pada kegaduhan penanganan Covid-19 di Daerah. Inkonsitensi kebijakan pusat sangat berdampak luar biasa terhadap daerah karena sebagai negara 
kesatuan daerah diwajibkan patuh terhadap kebijakan pusat dan tidak boleh bertentangan dengan kebijakan yang lebih tinggi. Hal yang cukup menarik yang dapat diamanati dalam hal hubungan pemerintah dalam bencana pandemi Covid-19 ini adalah manuver pemerintah pusat dan pemerintah daerah dalam menangani pandemi Covid-19 ini yang menimbulkan gesekan antar kewenangan pusat dan daerah serta sangat berimplikasi pada kebijakan daerah.

\section{Kajian Teori}

1. Hubungan Pemerintah Pusat dan Daerah

Menurut Undang-Undang Dasar 1945 pasal 18 ayat (1) dan (2) menyebutkan bahwa Negara Kesatuan Republik Indonesia dibagi atas daerahdaerah provinsi dan daerah provinsi itu dibagi atas kabupaten dan kota, yang tiap-tiap provinsi, kabupaten dan kota itu mempunyai pemerintahan daerah yang diatur dengan undang. Pemerintah provinsi, kabupaten dan kota berhak mengatur dan mengurus sendiri pemerintahannya berdasarkan azas otonomi daerah dan azas pembatuan. Menurut Hoessein, dkk (2004) Indonesia adalah negara kesatuan yang terdesentralisasi (decentralized unitary state; Gedecentraliseerde Eenheidsstaat). Sebagai konsekuensinya berarti pemerintahan daerah merupakan subdivisi dari pemerintah pusat (Nurcholis, 2007). Yang artinya antara pemerintah pusat dan pemerintah daerah terdapat hubungan yang tidak bisa dipisahkan.

Ahli yang terkenal mendefinisikan konsep desentralisasi dan sampai dengan sekarang definisinya masih dipakai adalah Dennis A. Rondenelli. Dalam bukunya yang berjudul Decentralization in Developing Countries $A$ Review of Recent Experience menyatakan : "Decentralization can be defined as the transfer of responsibility for planning, management and resource raising and allocation from the central government and its agencies to: (a) field units of central government ministries or agencies, (b) subordinate units or levels of government, (c) semiautonomous public authorities or corporations, (d) areawide, regional or functional authorities, or (e) nongovernmental private or voluntary organization" (Rondenelli, Nellis, \& Cheema, 1983). Jadi desentralisasi menurut Rondenelli adalah transfer 
tanggung jawab dari pemerintah pusat yang berkaitan dengan perencanaan, pengelolaan pemerintah, sumber daya yang ada dan juga alokasi dana kepada unit yang pemerintahan yang lebih rendah, semiotonom otororitas publik atau perusahaan, otororitas regional ataupun daerah, organisasi non pemerintahan ataupun LSM.

Sedangkang menurut Dimce Nikolov (Setiawan, 2018) desentralisasi adalah pengalihan fungsi publik berupa wewenang dan tanggung jawab dari pemerintah pusat kepada daerah, civil society dan non government organization (NGO) lainnya.

Lain halnya dengan Nikolov, Logemann menyebutkan desentralisasi sebagai pelimpahan kekuasaan dari penguasa negara kepada perserikataan pemerintahan mandiri. Lebih lanjut dekonsentrasi (ambtelijke decentralisatie) merupakan bagian dari desentralisasi (Karianga, 2013).

Secara rinci Rondenelli (Rondenelli, Nellis, \& Cheema, 1983) telah membagi desentralisasi menjadi 4 tipe yang telah diterapkan dibeberapa pemerintahan baik diterapkan secara bersamaan adapula dengan waktu yang berbeda sesuai dengan hasil evaluasi pemerintahan negara-negara yang menerapkan desentralisasi, yaitu :

1. Dekonsentrasi adalah penyerahan atau pengalihan sejumlah wewenang dan tanggung jawab administrasi kepada tingkat yang lebih rendah dalam organisasi atau otoritas pemerintah pusat di daerah dengan panduan dan arahannya ditetapkan oleh pemerintah pusat. Dalam implementasinya pemerintahan daerah dimungkinkan untuk mengidentifikasi masalah, merumuskan perencanaan dan penerapkan kebijakan tetapi harus sesuai dengan tujuan yang ditetapkan pemerintah pusat.

2. Delegasi adalah pengalihan tanggung jawab manajerial seperti fungsifungsi pemerintahan tertentu kepada organisasi diluar struktur birokrasi yang secara tidak langsung dikendalikan oleh pemerintah pusat atau perusahaan publik, badan otoritas regional atau disebut lembaga semi otonom.

3. Devolusi adalah penciptaan atau penguatan unit pemerintah daerah secara finansial maupun legal yang secara substansi berhak tidak dikontrol oleh pemerintah pusat. Dalam devolusi pemerintah daerah sifatnya otonom dan independen dan secara status hukum terpisah 
dari unit pemerintah pusat. Pemerintah daerah mempunyai batas geografis sebagai daerah otoritasnya, menjalankan fungsi eksekutif, memiliki sumber daya dalam hal meningkatkan pendapatan dan pengeluaran daerah, orientasi pada kepuasan masyarakat. Pemerintah daerah tidak hanya bawahan secara administrasi pemerintah pusat tapi bisa berinteraksi timbal balik dengan pemerintah pusat.

4. Privatisasi yaitu pelepasan tanggung jawab pemerintah pusat pada perusahaan swasta, LSM dan Badan Usaha Milik Negara atau Daerah.

2. Implementasi Kebijakan

Terdapat 3 pendekatan teoritis berbeda dalam studi implementasi kebijakan publik dalam Handbook of Public Policy Analysis Theory, Politics, and Methods (Fischer, Miller, \& Sidney, 2007) yaitu :

1. Pendekatan top-down

Yaitu memberikan penekanan utama pada kemampuan para pengambil keputusan untuk menghasilkan tujuan kebijakan yang objektif dan mengendalikan pada tahap implementasinya. Pendekatan top-down, implementasi kebijakan dimulai dengan keputusan yag dibuat oleh pemerintah pusat. Para ahli dalam pendekatan top-down yaitu Pressman dan Wildavsky (1973), Van Meter dan Van Horn (1975), Bardach (1977), serta Sabatier dan Mazmanian (1979, 1980, 1983). Mereka mengasumsikan hubungan sebab akibat langsung antara kebijakan dan hasil yang diamati dan cenderung mengabaikan dampak pelaksana terhadap proses delivery kebijakan. Dalam pendekatan ini kebijakan sebagai input dan implementasi sebagai faktor output. Menurut deLeon menggambarkan pendekatan topdown sebagai "fenomena elit yang mengatur".

Menurut Sabatier dan Mazmanian menetapkan enam kriteria untuk implementasi yang efektif: (1) tujuan kebijakan jelas dan konsisten, (2) program didasarkan pada teori kausal yang valid, (3) proses implementasi terstruktur dengan memadai, (4) pejabat pelaksana berkomitmen untuk tujuan program, (5) kelompok kepentingan dan kedaulatan (eksekutif dan legislatif) mendukung, dan (6) tidak ada perubahan yang merugikan dalam kondisi kerangka sosial ekonomi. 


\section{Pendekatan bottom-up}

Awalnya merupakan kritik terhadap pendektan top-down, beberapa studi menunjukkan kebijakan yang sifatnya top-down tidak dapat mencapai tujuan kebijakan. penelitian ini biasanya dimulai dari "bawah" dengan mengidentifikasi implementator kebijaka. Mereka menolak gagasan bahwa kebijakan didefinisikan di tingkat pusat dan bahwa daerah sebagai pelaksana harus berpegang teguh pada tujuan-tujuan ini serapi mungkin. Sebaliknya, Birokrasi daerah dianggap lebih dekat dengan masalah dari pada pembuat kebijakan ditingkat pusat. Peneliti bottom-up klasik adalah: Peneliti Amerika Lipsky (1971, 1980) dan Elmore (1980) Hjern, Porter dan Hull (1982). Lipsky berpendapat bahwa analis kebijakan perlu mempertimbangkan interaksi langsung antara aktivis sosial dan warga negara.

\section{Pendekatan hybrid}

Untuk mengatasi kesenjangan antara dua pendekatan lainnya dengan memasukkan unsur top-down, bottom-up dan model teoritis lainnya.

\section{Metode Penelitian}

Penelitian ini merupakan penelitian kualitatif dengan menggunakan pendekatan diskriptif kualitatif. Penelitian Kualitatif menurut Denzin dan Lincoln adalah penelitian dengan latar ilmiah dengan tujuan untuk menafsirkan fenomena yang ada dengan beberapa metode (Anggito \& Setiawan, 2018). Teknik pengumpulan data menggunakan metode dokumentasi atau biasa dikenal studi pustaka. Studi pustaka digunakan karena keterbatasan ruang gerak penulis yang dikarenakan kondisi pandemic Covid-19 sehingga tidak memungkinkan untuk melaksanakan wawancara langsung. Selain itu mendukung program pemerintah untuk tetap produktif walau dikondisi yang terbatas. Oleh karena itu sumber data yang digunakan dalam penelitian ini adalah data sekunder yaitu data yang diperoleh dari jurnal, website pemerintah, media elektronik, Perundang-Undangan, dan kajian lainnya. 


\section{Pembahasan}

Kecepatan dan konsistensi kebijakan pemerintah dalam menghadapi Pandemi Covid-19 menjadi ujung tombak keberhasilan negara-negara dunia mengendalikan dan menekan penyebaran virus Covid-19 ini. Memperhatikan wabah ini tidak peduli dengan kerumitan dan kelembagaan dan struktur pemerintah yang berlapis-lapis. Menurut McConnel Gagalnya sinergi dan koordinasi antar elemen dalam merespon ancaman pandemi akan dibayar mahal dengan krisis kemanusian yang mendalam (Mas'udi \& Winanti, 2020). Apalagi musuh yang kita hadapi pada pandemi tidak terlihat dan diperlukan deteksi medis yang rumit membuat negara-negara dituntut tidak gagap menggambil kebijakan yang strategis.

Penulis menemukan menemukan beberapa inkonsitensi kebijakan pemerintah Pusat dalam menangani pandemi Covid-19 ini yang berujung pada krisis hubungan pemerintah pusat dan daerah :

1. Pembatasan Sosial Berskala Besar VS New Normal

Diawal pandemi ini pemerintah mengalami kegundahan dalam menentukan kebijakan apakah akan melakukan Lockdown seperti yang dilakukan negara-negara dunia lainnya yang menelan anggaran yang cukup besar atau melalukan tes massal seluruh rakyat Indonesia yang sama-sama menelan anggaran yang besar atau membiarkan saja Covid-19 mematikan rakyatnya. Kemudian diambillah kebijakan "pengindonesiaan" Lockdown yang sekarang kita kenal Pembatasan Sosial Berskala Besar (PSBB) yang mana kebijakan ini di hulu ditetapkan oleh Pemerintah Pusat melalui Keputusan Menteri Kesehatan dan dihilirnya dilakukan oleh pemerintah Daerah. Aturan PSBB tercatat dalam Peraturan Pemerintah Nomor 21 tahun 2020 dan Peraturan Menteri Kesehatan Nomor 9 Tahun 2020 yang didalamnya mengamanatkan pembatasan meliputi peliburan sekolah dan tempat kerja, pembatasan kegiatan keagamaan, pembatasan pada fasilitas umum, pembatasan acara budaya, pembatasan transportasi umum. Sedangkan Lockdown berarti kondisi dimana masyarakat tidak boleh meninggalkan tempat tinggal sama sekali kecuali untuk hal yang bersifat urgent (Septiasputri, 2020). Menurut Pengamat Kebijakan Publik Universitas Padjadjaran, Yogi Suprayogi Sugandi menjelaskan, PSBB dan Lockdown sebenarnya hampir sama yang membedakan cakupan wilayah 
dan sanksi. PSBB lebih lokal cakupannya kabupaten/Kota atau beberapa Kabupaten/Kota saja sementara Lockdown bisa satu negara seperti Spanyol, Italia. Sedangkan sanksi PSBB lebih ringan (Soft) ditentukan oleh pemerintah daerah sedangkan Lockdown keras (Hard) (Zilkhair, 2020). Menurut data Gugus Tugas Percepatan Penangan Covid-19 terdapat 24 wilayah yang menerapkan PSBB yaitu 4 Provinsi dan 20 Kabupaten/Kota dan sampai dengan tanggal 1 Juni 2020 tersisa 4 Provinsi dan 15 Kabupaten Kota yang masih menerapkan PSBB dan data terakhir pada 7 Desember 2020 hanya tersisa 2 Provinsi dan 5 kabupaten/kota yang masih masih menerapkan PSBB ini (BNPB, 2020).

Provinsi Pertama yang ditetapkan menerapkan PSBB adalah DKI Jakarta yaitu pada tanggal 10 April 2020. Kebijakan PSBB diberikan dengan masa berlaku selama 14 hari dan dapat diperpanjang sesuai dengan permintaan dan hasil Evaluasi Tim Gugus Tugas Pusat bersama Kemeneterian Kesehatan. PSBB di ajukan Kabupaten/Kota kepada Provinsi yang kemudian diteruskan kementerian Kesehatan untuk ditetapkan melalui keputusan Menteri Kesehatan. Dan sampai sekarang DKI Jakarta masih dengan status PSBB.

Kebijakan PSBB sebenarnya cukup terlambat diambil pemerintah. Karena banyak Daerah yang telah melakukan penetapan kejadian Luar Biasa Covid-19 (KLB) dan melakukan karantina lokal ataupun pembatasan aktifitas warganya. Sebut saja Kota Tegal yang melakukan Local Lockdown pada 22 Maret 2020 jauh sebelum adanyanya kebijakan PSBB yang sempat menjadi konflik antar pemerintah Kota Tegal dan Provinsi Jawa Tengah salah satunya hanya jalan-jalan provinsi saja yang dapat dilalaui bebas sedangkan jalan kota ditutup penggunaannya. Kota Tasikmalaya juga melakukan Lockdown daerah pada 31 Maret 2020 pasca ditemukannya 5 pasien positif. Papua yang menutup seluruh akses masuk dan keluar Papua pasca ditemukannya 1 Pasien positif Covid-19 yaitu ditutupnya Bandara Sentani Papua (Suwandi, 2020).

Hal dilematis lain yang dialami daerah yang menerapkan PSBB adalah kurangnya Anggaran. Dengan menerapkan PSBB daerah bertanggungjawab memberikan insentif berupa bantuan sosial baik tunai ataupun bahan pokok makanan kepada masyarakat yang terkena imbas PSBB. Sayangnya banyak 
daerah di Indonesia mengalami defisit anggaran yang menyebabkan banyak daerah enggan menerapkan PSBB. Pemerintah melalui Kementerian Sosial memang mengganggarkan Rp. 203,9 triliun (Kementerian Keuangan, 2020) untuk perlindungan sosial tetapi tidak dapat mengakomodasi masyarakat secara keseluruhan yang terkena dampak salah satunnya akibat PHK. Hal ini yang menyebabkan pada awal-awal penerapan PSBB banyak daerah tidak melakukannya yang membuat kebijakan implementasi PSBB didaerah dilakukan secara parsial saja yaitu hanya daerah yang mampu saja, sementara daerah yang tidak mampu tidak menerapkannya karena memerlukan anggaran yang cukup besar.

Belum selesai dengan PSBB Indonesia kini Indonesia menggencarkan kebijakan New Normal atau Normal Baru. Dalam pernyataan Presiden Joko Widodo yang menyatakan bahwa kita harus berdamai dan hidup berdampingan dengan virus Covid-19 dengan cara melaknasanakan New Normal. Pernyataan ini cukup mendapat kritikan salah satunya mantan presiden Jusuf Kalla yang mengkritik penggunaan kata berdamai menurutnya "virus ganas dan tidak milih-milih siapa dan tidak bisa diajak berdamai bilamana kedua belah pihak sepakat untuk berdamai. Kalau kita hanya ingin damai, tapi virusnya endak bagaimana?". Dalam penangan ini pemerintah harus serius dan bukan berarti menjadikan damai dengan virus dengan resiko mati (Priadmojo \& Permadi, 2020). Kemudian muncul aksi penolakan dari publik terkhususnya dari tenaga kesehatan yang sempat viral melalui sosial media \#indonesiaterserah dan \#terserahindonesia yang mengindetifikasi kekecewaan publik terhadap inkonsistensi kebijakan pemerintah.

Kebijakan New Normal sendiri mau tidak mau diterapkan ditengah gempuran Covid-19 di Indonesia. Hal ini menurut pemerintah karena PSBB berkepanjangan ternyata menimbulkan efek ekonomi yang cukup besar bagi Indonesia. Tercatat terjadi ribuan buruh di PHK, perusahaan bangkrut, sektor ekonomi terpuruk yang akhirnya berimbas pada masuknya perekonomian pada resesi pada kuartal ke-3 Tahun 2020 ini. Resesi menurut Kamus Besar Bahasa Indonesia adalah kelesuan dalam kegiatan dagang, industri, dan sebagainya (seolah-olah terhenti); menurunnya (mundurnya, berkurangnya) kegiatan dagang (industri). Menurut Julius Shikin (Rodeck, 2020), Resesi ditandai dengan adanya penurunan PDB secara dua kuartal berturut-turut. 
Resesi ekonomi bukan hanya terjadi di Indonesia saja, banyak negara besar yang juga terkena resesi sebut saja Singapura, Amerika Serikat dan Negara lainnya.

Menurut para ahli berdasarkan sejarah wabah Flu Spanyol tahun 1919 yang banyak menelan korban mematikan adalah serangan wabah ini pada gelombang kedua. Dimana masyarakat dan pemerintah mulai acuh dan menyepelepakan infeksi ini akibat eforia kebebasan. Sebenarnya Indonesia telah diperingatkan WHO tentang gelombang kedua Covid-19. Banyak kritikan para ahli salah satunya epidemiologi Universitas Indonesia, Pandu Riono (Rahim, 2020). Menurutnya dasar penerapan New Normal ini adalah angka reproduksi yang menurun. Untuk dapat menghitung angka reproduksi virus Covid-19 ini dibutuhkan data-data persebaran yang akurat. Saat ini belum tepat untuk melaksanakan New Normal.

Dengan banyaknya kabar simpang siur dan perdebatan tentang New Normal Gugus Tugas Pusat Percepatan Penanganan COVID-19 pada Bulan Juni memberikan kewenangan kepada 102 Pemerintah Kabupaten/Kota yang pada saat ini berada atau dinyatakan dalam zona hijau, untuk melaksanakan kegiatan masyarakat produktif dan aman COVID-19. Kabupaten Kota tersebut merupakan rekomendasi dari tim pakar melalui berbagai pendekatan. Pendekatan yang dipakai adalah berdasarkan kriteria epidemologi, surveilans kesehatan masyarakat dan pelayanan kesehatan sesuai rekomendasi Badan Kesehatan Dunia (WHO). Pemerintah menggunakan frase "kegiatan masyarakat produktif dan aman COVID-19" untuk mengadopsi istilah New Normal. Dan kemudian berubah kembali dengan yang sekarang kita kenal menjadi adaptasi kebiasaan baru dengan penerapan 3T. 3T sendiri yaitu Tracking, Testing dan Treatment.

Menurut data yang dipaparkan Ismail Fahmi $^{2}$ berkaitan dengan Kampanye New Normal dari tanggal 16 Mei - 6 Juni 2020, terdapat kenaikan trend percakapan New Normal sejak tanggal 26 Mei 2020 yang bermakna bahwa "tidak ada orang yang bisa melawan secara opini kebijakan New Normal ini". Selain itu percakapan New Normal didorong oleh 3 aktivitas yaitu tim kampanye New Normal oleh tim media pemerintah, Tim New Normal

\footnotetext{
2 Webinar LP3ES : Pemaparan Hasil Big Data LP3ES tentang Kebijakan New Normal Tanggal 9 Juni 2020
} 
Jaringan Humas Polri, dan respon publik yang tidak yakin Indonesia siap dengan New Normal. Hal ini juga bisa kita identifikasikan bahwa pemerintah dalam mengambil kebijakannya sifatnya Top-Down. Pemerintah menggunakan saluran-saluran publik untuk mempengaruhi kebijakan yang diambil dengan cara kampanye media sosial, media massa yang mau tidak mau membuat kebijakan tersebut tak terbantahkan untuk dilaksanakan atau terkesan "memaksa secara halus". Ciri khas ini sama dengan kebijakan yang sifatnya Top-Down.

\section{Kebijakan Transportasi yang Labil}

Selanjutnya inkonsentasi yang terjadi yaitu berkaitan dengan kebijakan transportasi. Pertama, kebijakan pelarangan mudik, terhitung per tanggal 21 April 2020, pemerintah menetapkan larangan mudik untuk seluruh masyarakat yang terhitung efektif mulai tanggal 24 April 2020 melalui Permenhub Nomor 25 Tahun 2020. Sebelumnya polemik ini makin rumit ketika Presiden Jokowi mengungkapkan bahwa mudik dan pulang kampung itu berbeda pada wawancara di Program Mata Najwa Trans 7 Tanggal 22 April 2020. Menurut Presiden Jokowi pulang kampung dan mudik berbeda karena berbeda waktunya, pulang kampung dilakukan karena warga tidak punya pekerjaan lagi dikota kemudian pulang ke desanya sedangkan mudik dilaksanakan untuk merayakan hari raya idul fitri. Tapi kemudian argument ini diluruskan kembali oleh Najwa Shihab dalam akun Twitternya bahwa pernyataan Jokowi dilakukan sebelum adanya rapat terbatas 21 April yang menetapkan mudik dan pulang kampung dilarang.

Polemik mudik ini terus berlanjut, pasca penetapan pelarangan mudik yang merupakan tindakan yang sejalan dengan PSBB yang sedang gencar di lalukan daerah untuk menekan penyebaran virus ini dengan penutupan pintu masuk dan keluar masuk daerah dengan dihentikannya aktifitas penerbangan, pelabuhan dan transportasi darat, tiba-tiba pemerintah merombak kembali aturan ini dan melonggarkan masyarakat untuk bepergian dengan alasan khusus yang berimplikasi pada dibukanya kembali Bandara, Pelabuhan, Stasiun Kereta Api, Terminal Bus melaui Surat Edaran Gugus Tugas Nomor 4/2020 tentang Pembatasan Perjalanan Orang Dalam Rangka Percepatan penangan Covid-19 dan Surat Edaran Ditjen Hubla yang berlaku 7 Mei 2020. Yang terjadi adalah membludaknya penumpang di bandara Soekarno Hatta 14 
Mei 2020 yang tentunya menjadi viral yang mengenaskan. Menurut Alvien Lie (m.antaranews.com 14 Mei 2020) aturan Pembatasan perjalanan ini judulnya saja pembatasan tapi sebenarnya membuka peluang siapa saja boleh berpergergian.

Aturan transportasi kemudian berubah lagi demi menyesuaikan New Normal yang menurut pemerintah sudah layak dilakukan di Indonesia sebagai cara memulihkan industry tranportasi melaui Surat Edaran (SE) Gugus Tugas Percepatan Penanganan Covid-19 Nomor 9 Tahun 2020 tentang Kriteria dan Persyaratan Perjalanan Orang Dalam Masa Adaptasi Kebiasaan Baru Menuju Masyarakat Produktif dan Aman Corona Virus Desease 2019 (Covid-19) masyarakat yang akan berpergian menggunakan transportasi udara wajib melakukan Rapid Tes atau memiliki hasil Tes Swab PCR Negatif.

Dan yang terbaru untuk menghadapi libur natal dan tahun baru 2021 pemerintah melalui SE Menteri Perhubungan Nomor 22 Tahun 2020 menjadikan rapid antigen sebagai salah satu syarat keluar masuk pulau jawa diatur melalui dan berlaku mulai 20 Desember 2020. Rapid Tes yang sebelumnya mengambil sempel darah atau disebut rapid tes antibodi sedangkan rapid tes antigen ini mengambil sampel dari cairan tenggorokan dan hidung. Kebijakan ini diambil karena rapid tes sebelumnya dianggap tidak efektif mendeteksi Covid-19 sedangkan dengan rapid tes antigen lebih efektif dan membutuhkan waktu yang lebih sedikit ketimbang tes swab PCR yang memakan waktu yang cukup lama untuk mengetahui hasilnya.

Kemudian apa yang terjadi di daerah akibat begitu cepatnya perubahan kebijakan transportasi ini? Ternyata banyak kasus terjadi di Daerah akibat dari berpergian dari luar kota. akibatnya muncul klaster-klaster baru yang bersinggungan yaitu klaster keluarga dan klaster perkantoran. Karena interaksi yang paling banyak dari mutasi orang dari satu tempat ketempat lain bersinggungan dengan keluarga dan teman kantor. Belum lagi pada awal-awal pemberlakuan syarat Rapid Tes sebagai syarat naik moda trasportasi terjadi lonjakan permintaan rapid tes yang membuat melambungnya harga Rapid tes di daerah hingga mencapai jutaan rupiah. Akhirnya daerah-daerah yang sebelumnya belum terinfeksi kini hampir seluruh daerah di Indonesia mengalami peningkatan pasien Covid-19. Akibatnya Rumah sakit di daerah kelebihan kapasitas pasien, bahkan 
beberapa rumah sakit tutup akibat tenaga kesehatannya terinfeksi virus Covid-19. Dengan adanya kebijakan rapid tes antigen yang terbaru ternyata hal ini kembali terulang. Salah satunya yang terjadi di Bandara Soekarno Hatta pada Tanggal 20 Desember 2020 terjadi ledakan antrian rapid antigen.

3. Monopoli Kebijakan Kesehatan oleh Pemerintah

Pandemi Covid-19 memanglah bukan hanya masalah masalah kesehatan saja tapi multi masalah yang patut diperhatikan yang menjadi data rujukannya tentulah data yang berasal dari data kesehatan. Banyak bentuk monopoli kebijakan kesehatan yang dilakukan pemerintah yang akhirnya membuat pemerintah lamban dan inkonsisten. Pertama, penggunaan masker kesehatan. Awal mula konfirmasi Covid-19 dinyatakan bahwa masker kesehatanlah yang mampu menangkal virus Covid-19, yang berakibat pada kegaduhan masyarakat kenaikan harga masker, aksi borong besar-besaran sampai penimbunan masker. Dengan adanya kericuhan ini Menteri Kesehatan mengeluarkan pendapatnya bahwa masker hanya digunakan oleh orang yang sakit dan yang sehat tidak perlu menggunakan masker karena dengan kekuatan Doa Indonesia terbebas dari Covid-19 yang berujung pada blunder. Kemudian akhirnya atas rekomendasi WHO penggunaan masker kain wajib untuk masyarakat yang beraktifitas diluar ruangan dana dal ruangan serta penggunaan masker kesehatan digunakan oleh tenaga kesehatan dan pasien positif.

Kedua, monopoli pengujian Laboratorium Spesimen pasien Virus Covid-19. Kita tahu diawal Maret 2020 hanya laboraturium Kementerian Kesehatan yang berkedudukan di Jakarta saja yang bisa menguji Spesimen virus ini. Akibatnya angka positif Covid-19 yang terdeteksi sedikit tapi tingkat kematiannya tinggi diatas rata-rata dunia. Selain itu hal ini berimplikasi pada ketidakakuratan data pasien positif Covid-19. Sudah beberapa kali pemerintah melalui Jubir Gugus Tugas Penanganan Percepatan Covid-19 merevisi pengumumannya dan pemerintah daerah konfirmasi kasus yang tidak sesuai antara data pusat dan daerah. Dan hingga sekarang antara data satgas Covid-19, Situs WHO, dan situs pemerintah daerah sering terjadi ketidak sinkronan data tersebut.

Selain itu mengenai konfirmasi kasus positif ini juga pemerintah terkesan tidak transparan. Hal ini dibuktikan dengan pengumuman pada masa awal bahwa pemerintah tidak mengumumkan secara terbuka keterkaitan 
kontak antar satu pasien dengan pasien lainnya. Bahkan perkembangan kasus harian Covid-19 ini sejak akhir September tidak diumukan lagi melalui siaran langsung pada TV Nasional. Padahal dengan tidak transparannya data ini menurut IDI yang mengakibatkan memperparah jumlah tenaga kesehatan yang tertular Covid-19 dari pasien yang ditangani (Eko, 2020) karena masyarakat merasa sudah mulai aman dan menganggap biasa Covid-19 ini. Menurut data IDI pertanggal 15 Desember 2020 terdapat 363 tenaga kesehatan yang meninggal dengan rincian dokter yang meninggal dunia tersebut terdiri dari 107 dokter umum (4 guru besar), 92 dokter spesialis ( 7 guru besar), 2 dokter residen dan 1 masih dalam verifikasi, 5 dokter gigi dan 146 perawat (Pranita, 2020).

Ketiga, Monopoli pemerintah pada Rumah Sakit Darurat Khusus Covid19. Terhitung pemerintah mendirikan 2 Rumah Sakit Darurat Khusus Covid19 yaitu di Wisma Atlet Jakarta dan Rumas Sakit Darurat Khusus Covid-19 di Pulau Galang Batam. Pasien yang bisa masuk kedalam fasilitas ini adalah yang mendapat rekomendasi dari pemerintah pusat. Seperti yang belum lama terjadi pada Rumah Sakit Darurat Khusus Covid-19 Pulau Galang Batam, keadaan rumah sakit di wilayah Kota Batam mengalami over kapasitas sehingga merujuk pasien Covid-19 ke Rumah Sakit Darurat Khusus Covid-19 Pulau Galang Batam tapi hal ini ditolak operasional rumah sakit dikarenakan pengoperasiannya hanya untuk menangani TKI dan kru kapal yang pulang dari luar negeri (Maulana, 2020). Baru setelah mendapat protes keras dari pemko Batam dan Provinsi Kepulauan Riau pasien positif dapat diterima. Sangat disayangkan, ketika aturan mengalahkan rasa kemanusian.

Selanjutnya, tentang Vaksin. Sampai sekarang masih vaksin Covid-19 ini masih terkesan parsial di Dunia. Amerika Serikat, Inggris dan Arab Saudi Akhir Desember ini akan melakukan vaksinasi kepada warganya. Indonesia sendiri juga akan menempuh hal yang sama melalui 2 kategori vaksin yaitu melalui vaksin buatan sendiri dan vaksin Impor. Untuk pembuatan vaksin sendiri melalui program vaksin merah putih baru akan uji klinis pada tahun 2021. Sedangkan vaksin impor, pemerintah melalui Bio Farma bekerja sama dengan SINOVAC salah satu produsen vaksin asal Cina telah melakukan uji klinis tahap ketiga vaksin Covid-19 yaitu melalui penyuntikan kepada 1620 relawan di Bandung (Sulistyawati, 2020). Uji klinis ini dilakukan melalui 2 kali 
suntikan yaitu pertama dalam rentang waktu Agustus-September. Dan suntikan kedua pada Oktober-November (CNN Indonesia, 2020).

Vaksin Covid-19 Sinovac sampai dengan Desember 2020 belum mengeluarkan evaluasi hasil uji klinis yang dilakukan. Badan Pengawas Obat dan Makanan (BPOM) rencananya mengeluarkan Emergency Use Of Authorization (EUA) untuk vaksin Covid-19 pada pekan ketiga Januari 2021 berdasarkan hasil uji klinis sementara. (BBC Indonesia, 2020) (CNN Indonesia, 2020). Persoalan yang timbul adalah pemerintah pada 6 Desember 2020 pemerintah Indonesia telah mengimpor 1,2 juta dosis vaksin dengan hasil uji yang masih sampai sekarang belum jelas. Akibat dari ketidakjelasan izin ini adalah terjadi penolakan dari tenaga kesehatan yang merupakan kelompok prioritas dari penerima vaksin ini karena dianggap tidak aman.

Polemik lainnya adalah berdasarkan Kepmenkes Nomor HK01.07/Menkes/9860/2020 Tanggal 3 Desember 2020 pemberian vaksin Covid-19 di Indonesia melalui 2 skema yaitu gratis ditanggung pemerintah melalui Kementerian Kesehatan dengan jumlah penerima 32 Juta orang dan berbayar mandiri yang akan dikoordinir oleh Kementerian BUMN dengan target 75 juta orang. Kebijakan ini cukup menjadi polemic dan mendapat tentangan berbagai pihak sehingga menjadi bola liar di masyarakat. Karena untuk membentuk kekebalan kelompok sebagai tujuan vaksinasi dibutuhkan minimal $67 \%$ orang divaksinasi dalam suatu negara. Bayangkan saja vaksinasi yang gratis di Indonesia masih banyak masyarakat yang tidak melakukan vaksinasi apalagi bila berbayar. Contoh saja untuk vaksin polio yang sudah gratis di Indonesia, baru $47.1 \%$ warga Indonesia yang mendapatkan vaksinasi.

Akhirnya pada tanggal 16 Desember 2020, presiden Joko Widodo mengumumkan bahwa vaksin Covid-19 akan gratis diterima oleh semua rakyat Indonesia dan siap untuk menjadi orang pertama yang disuntikan vaksin. Menurut penulis langkah ini cukup bijak diambil untuk mengakhiri polemik vaksin ini. Karena seperti yang dipaparkan pada latar belakang bahwa masalah yang dialami oleh masyarakat adalah kepercayaan pada pemerintah. Hanya saja menurut saya, pemerintah harus membuat kebijakan yang dikaji berbagai sumber dan sudut pandang berbagai ilmu pengetahuan. Sehingga kebijakan yang diambil bukan kebijakan yang mengedepankan ego sektoral semata. Karena dimasa seperti ini yang 
234 |Herni Marina.Inkonsistensi Kebijakan...

dibutuhkan masyarakat adalah pemerintah yang mampu menjamin masyarakatnya baik itu jaminan keselamatan maupun jaminan kepercayaan.

\section{Kesimpulan Dan Saran}

Pandemi Covid-19 bukan hanya masalah pemerintah pusat saja tetapi juga menjadi masalah bersama pemerintah daerah. Pemerintah daerah sebagai unsur pemerintahan yang paling dekat dengan masyarakat sangat erat tanggung jawabnya pada masyarakatnya. Inkonsistensi kebijakan pemerintah pusat mau tidak mau berbuah kekacauan di daerah. Tumpang tindihnya aturan yang dibuat pemerintah pusat serta begitu cepatnya perubahan aturan membuat daerah selaku implementator didaerah mengalami posisi dilematis. Disatu sisi pemerintah daerah harus taat dengan aturan dengan aturan yang dibuat pusat disisi lain desakan masyarakat menghasilkan aksi protes di daerah.

Kebijakan latah pemerintah pemerintah yang membuat daerah tergagap gagap bahkan menggagalkan daerah untuk dapat menekan penyebaran virus Covid-19 ini. Pola hubungan yang dibangun pemerintah dalam hal penangan Covid-19 ini juga haruslah partisipatif Bottom Up bukan seperti selama ini yang tergambar yaitu sentralistik Top Down. Ini tercermin berdasarkan kebijakan-kebijakan yang ditetapkan pemerintah tergambar bahwa menggunakan pendekatan Top-Down. Sebenarnya tidak salah menggunakan pendekatan Top-Down hanya harus disyaratkan konsistensi dalam pengambilan kebijakan. Inkosistensi dalam kebijakan bukan hanya membuat kebijakan itu tidak efektif tetapi makin membuat banyak korban baik korban manusia dan juga korban sistem. Karena dengan makin banyaknya inkonsistensi membuat masyarakat semakin apatis dengan masalah pandemi ini yang makin menimbulkan semakin meningkatnya masyarakat yang terinfeksi. Karena biaya untu mengobati satu pasien memerlukan biaya yang cukup besar yang harus ditanggung negara. Tanggungan negara secara tidak langsung juga menjadi tanggungan masyarakat. 
Dalam sistem pemerintahan Negara kesatuan memang Pemerintah Pusat menjadi Center arah kebijakan pemerintahan tapi dengan dengan Negara Kesatuan yang terdesentralisasi Daerah punya peran lebih besar dari pemerintah pusat karena yang bersentuhan langsung dengan masyarakatnya dan dalam penanganan Covid-19 seperti ini episentrum penyebaran virus adalah daerah. Dengan penerapan kebijakan yang inkonsistensi dan dampak dari negara kesatuan yang mewajibkan daerah wajib patuh dengan pemerintah pusat menjadikan kebijakan yang diambil oleh pemerintah pusat haruslah sifatnya koordinatif bukan manipulatif. Sehingga kebijakan yang diambil akan meningkatkan kepercayaan berbagai sektor sebagai jalan keluar terbaik.

\section{DAFTAR PUSTAKA}

\section{Buku-buku}

Anggito, A., \& Setiawan, J. (2018). Metodologi Penelitian Kualitatif. Sukabumi: CV. Jejak.

Fischer, E. b., Miller, G. J., \& Sidney, M. S. (2007). Handbook of Public Policy Analysis Theory, Politics, and Methods. Boca Raton: CRC Press.

Hoessein, B., Maksum, I. R., Riduansyah, M., \& Hanafi, P. N. (2004). Naskah Akademik Tata Hubungan Kewenangan Pemrintah Pusat dan Daerah. Jakarta: Pusat Kajian Pembangunan Administrasi Daerah dan Kota FISIP UI.

Karianga, H. (2013). Politik Hukum dalam Pengelolaan Keuangan Daerah. Jakarta: Kencana.

Kurniawan, N. I., Prastyo, W., Pamungkas, W. A., Ardianto, V., \& Farid, M. (2020). Policy Brief : Kepercayaan Publik terhadap Pemerintah dalam Penanganan Covid-19. Yogyakarta: PolGov.

Mas'udi, W., \& Winanti, P. S. (2020). Tata Kelola Penangan COVID-19 di Indonesia : Kajian Awal. Yogyakarta: Gadjah Mada University Press.

Nurcholis, H. (2007). Teori dan Praktik Pemerintahan dan Otonomi Daerah. Jakarta: PT. Grasindo. 
236 Herni Marina.Inkonsistensi Kebijakan...

Rondenelli, D. A., Nellis, J. R., \& Cheema, G. S. (1983). Decentralization in Developing Countries A Review of Recent Experience. Washington DC: The World Bank.

Setiawan, I. (2018). Handbook Pemerintahan Daerah. Yogyakarta: WR.

\section{Jurnal}

Agustino, L. (2020). Analisis Kebijakan Penanganan Wabah Covid-19 : Pengalaman Indonesia . Jurnal Borneo Administrator, 16 (2), , 253270.

Ginanjar, D. (2020). Peran Pemerintah Daerah Pada Penanganan Covid-19 . Jurnal Politik Pemerintahan Dharma Praja Vol 13 No. 1, 52-68.

Gustomy, R. (2020). Pandemi ke Infodemi: Polarisasi Politik dalam Wacana Covid-19 Pengguna Twitter. JIIP: Jurnal Ilmiah Ilmu Pemerintahan Volume 5,Nomor 2, 190-205.

Muhyiddin. (2020). Covid-19, New Normal dan Perencanaan Pembangunan di Indonesia . The Indonesian Journal of Development Planning Volume IV No. 2 - Juni, 240-252.

Muis, A. R. (2020). Transparansi Kebijakan Publik Sebagai Strategi Nasional Dalam Menanggulangi Pandemi Covid-19. SALAM; Jurnal Sosial \& Budaya Syar-I Vol. 7 No. 5, 439-454.

Rembulan, G. D., Wijaya, T., Palullungan, D., Alfina, K. N., \& Qurthuby, M. (2020). Kebijakan Pemerintah Mengenai Coronavirus Disease (COVID19) di Setiap Provinsi di Indonesia Berdasarkan Analisis Klaster . Journal of Industrial Engineering Systems Vol. 13, No. 2, 74-86.

Samudro, E. G., \& Madjid, M. A. (2020). Pemerintah Indonesia Menghadapi Bencana Nasional Covid -19 Yang Mengancam Ketahanan Nasional. Jurnal Ketahanan Nasional Vol. 26, No. 2, Agustus 2020, 132-154.

Sulistiani, K., \& Kaslam. (2020). Kebijakan Jogo Tonggo Pemerintah Provinsi Jawa Tengah dalam Penanganan Pandemi Covid-19 . Vox Populi Volume 3, Nomor 1, Juni 2020, 31-43. 
Yunus, N. R., \& Rezki, A. (2020). Kebijakan Pemberlakuan Lockdown Sebagai Antisipasi Penyebaran Corona Virus Covid-19. SALAM; Jurnal Sosial \& Budaya Syar-i Vol. 7 No. 3 , 227-238.

\section{Data Internet}

BBC Indonesia. (2020, Desember 15). Diambil kembali dari BBC Indonesia: https://www.bbc.com/indonesia/indonesia-55304188

BNPB. (2020, Desember 15). BNPB_Indonesia. Diambil kembali dari Twitter: https://twitter.com/BNPB_Indonesia/status/1338771402166476800

CNN Indonesia. (2020, November 18). CNN Indonesia. Diambil kembali dari CNN Indonesia: https://www.cnnindonesia.com/nasional/20201118121754-20571291/unpad-sebut-uji-klinis-vaksin-sinovac-berakhir-mei-2021

CNN Indonesia. (2020, Desember 17). CNN Indonesia. Diambil kembali dari CNN Indonesia: https://www.cnnindonesia.com/teknologi/20201216182000-199583106/alasan-vaksin-corona-sinovac-brazil-duluan-keluar-dari-ri

Eko. (2020, Desember 16). Merdeka. Diambil kembali dari Merdeka: https://www.merdeka.com/peristiwa/idi-minta-pemerintah-buka-datapasien-covid-19-kepada-tenaga-medis.html

Kementerian Keuangan. (2020). www.kemenkeu.go.id. Dipetik Desember 21, 2020, dari https://www.kemenkeu.go.id/covid19

Maulana, H. (2020, April 27). kompas.com. (A. Gabrillin, Editor) Diambil kembali dari https://regional.kompas.com/read/2020/04/27/06522141/faktapasien-corona-ditolak-rs-khusus-covid-19-pulau-galang-dianggapkarena?page $=$ all

Pranita, E. (2020, Desember 16). Kompas. (H. K. Sumartiningtyas, Editor) Diambil kembali dari Kompas: https://www.kompas.com/sains/read/2020/12/16/070200323/363tenaga-medis-meninggal-karena-covid-19-ini-3-saran-dariidi?page $=$ all

Priadmojo, D., \& Permadi, E. (2020, Mei 19). viva.co.id. Diambil kembali dari https://www.viva.co.id/berita/nasional/1276643-jk-kritik-jokowi-soalberdamai-dengan-corona

Rahim, A. (2020, Mei 30). kompas.tv. Diambil kembali dari kompas.com: https://www.kompas.tv/article/83856/full-ahli-epidemiologi-kritikkebijakan-new-normal

Rembulan, G. D., Wijaya, T., Palullungan, D., Alfina, K. N., \& Qurthuby, M. (2020). Kebijakan Pemerintah Mengenai Coronavirus Disease (COVID- 
238 |Herni Marina.Inkonsistensi Kebijakan...

19) di Setiap Provinsi di Indonesia Berdasarkan Analisis Klaster . Journal of Industrial Engineering Systems Vol. 13, No. 2, 74-86.

Septiasputri, M. D. (2020, April 23). rri.co.id. Diambil kembali dari rri.co.id: https://rri.co.id/humaniora/info-publik/826381/mengenal-perbedaanpsbb-dan-lockdown

Sulistyawati, R. L. (2020, Oktober 23). Republika. Diambil kembali dari Republika: https://republika.co.id/berita/qinqqw396/idi-relawan-yangikut-uji-klinik-vaksin-sinovac-sedikit

Suwandi, D. (2020, Maret 26). kompas.com. Diambil kembali dari ional.kompas.com/read/2020/03/26/10424101/cegah-penyebarancorona-di-papua-bandara-sentani-ditutup-hingga-9-april

Zilkhair, A. (2020, April 20). IDN Times Jabar. Dipetik April 20, 2020, dari IDN Times: https://jabar.idntimes.com/news/jabar/azziszilkhairil/pengamat-unpad-psbb-dan-lockdown-hampir-sama-bedanyapsbb-lebih-soft/4

\section{Peraturan Perundang-undangan}

Undang-Undang Nomor 23 Tahun 2014 Tentang Pemerintahan Daerah 